(C) Н.Л. Пушкарева, И.В. Богдашина

\title{
«ВКУСНАЯ И ЗДОРОВАЯ ПИЩА» В ПОВСЕДНЕВНЫХ ЖЕНСКИХ ПРАКТИКАХ НЕСТОЛИЧНОГО СОВЕТСКОГО ГОРОДА 1950-1960-х ГГ.
}

Советская женская повседневность в 1950-1960-х г2. редко бывает предметом пристального этнографического наблюдения. В иентре внимания данной статьи - ее такая важная сторона, как приобретение и заготовка продуктов питания, а именно вопросы, связанные с приготовлением пищи, обеспечением едой детей, родных и близких в условиях возрождавшегося после войны хозяйства Волгограда. Обращение к эго-документам крупного нестоличного региона Нижнего Поволжья позволило выявить и сравнить общее и особенное в повседневно-бытовых практиках приготовления пищи, уяснить отношение самих женщин к предпринимаемым государством попыткам облегчить их домашний труд как хозяек, выявить полулегальные (получение в обход очереди, из-под прилавка) и противозаконные (блат) способы «накармливания» своих семей. По мнению авторов, в условиях скрытого дефицита товаров женщины сталкивались со многими трудностями (очереди, нехватки, лишения), но неся бремя нескончаемых домашних дел, считали порой время, затраченное на них, формой отдыха и досуга. Домамнее, а не общественное питание, бьло основной формой потребления в провинциальном городе Нижнего Поволжья. Жительниць этого города, совмещуая множество социальных ролей, неся двойную нагрузку (на работе и дома), ежедневно выполняли свои обязательства, нанося ущерб профессиональным перспективам, здоровью, отдыху и, не осознавая этой дискриминации, продолжали выполнять вмененные им обществом традиционно «женские» домашние обязанности.

Ключевые слова: гендерная антропология, женский домашний труд, приготовление пищи, потребление, «хрущевская оттепель», Волгоград

Ссылка при цитировании: Богдашина И.В., Пушкарева Н.Л. «Вкусная и здоровая пища» в повседневных женских практиках нестоличного советского города 1950-1960-х гг. // Вестник антропологии, 2021. № 1 (53). С.

Повседневность - сфера человеческой обыденности, в которой приобретение продуктов и их приготовление, забота о соблюдении режима питания для себя и

Пушкарева Наталья Львовна - д.и.н., главный научный сотрудник, зав. центром гендерных исследований, Институт этнологии и антропологии им. Н.Н. Миклухо-Маклая РАН (119991 Москва, Ленинский просп., 32а. Эл. почта: pushkarev@mail.ru

Богдашина Ирина Владимировна - аспирант, Институт этнологии и антропологии им. Н.Н. Миклухо-Маклая РАН (Москва, Ленинский пр. 32А). Эл. почта: ira18bogdashina@mail.ru

*Подготовлено по плану НИР ИЭА РАН и проекту РФФИ № 19-09-00191 «Женская социальная память как консолидирующий потенциал многопоколенной семьи, укрепления государственности и российской нации (18-21 век)» 
близких составляют едва ли не самую важную для обеспечения жизнедеятельности часть. Столетиями в разных социальных слоях, даже самых обеспеченных, контроль над нею считался прерогативой женщин. Поэтому в рамках научного проекта по изучению женской нестоличной повседневности второй половины XX века обойти вниманием тему “вкусной и здоровой пищи”, (а именно так именовались советские кулинарные книги того времени) невозможно (Книга о вкусной 1952; Книга о вкусной 1954; Книга о вкусной 1961). Как и многие другие аспекты женского быта, этот может быть раскрыт наиболее полно при условии использования материалов устной истории, текстов опубликованных интервью и иных эго-документов, сохранивших пережитые события и реалии, в нашем конкретном случае - повседневной жизни горожанок крупного нестоличного региона Нижнего Поволжья. В распоряжении автоpa, помимо статей из женских периодических изданий, кулинарных книг и пособий, имеется более десятка неструктурированных биографических интервью, собранных в ходе полевой работы, а также - в числе редких архивных источников личного происхождения - особо ценные дневниковые записи хирурга 3.С. Седельниковой, жившей в Волгограде в 1950-1960-е гг. (ГАВО. Ф. Р-6880. Д. 13-35).

Тема женских бытовых практик 1950-х гг. и в ее рамках - всего, что связано с приобретением и приготовлением продуктов - оказалась в центре внимания социологов еще в те же 1950-е гг. (Араловец 1954: 160-161; Куприн 1959: 28). Именно тогда женщины-ученые сами первые заговорили об “облегчении домашних забот женщины”, о нужности сети общественного питания (Бильщай 1959: 242). В 1960-е гг. был поднят вопрос об “устранении остатков неравенства женщин в быту”, существование проблемы было признано, однако, речь не шла о том, чтобы и мужчины взялись выполнять часть “женских" домашних обязанностей, данная задача была возложена на государство. Появились первые научные публикации на эту тему (Белова 1965: 25-26). В 1970-1980-е гг. проблема удовлетворения бытовых потребностей продолжала оставаться в центре внимания ученых (Грушин 1967; Харчев, Голод 1971; Гордон, Клопов 1972). 3.А. Янкова рассуждала о гендерных ролях в семье и разделении домашнего труда, Е.М. Зуйкова полагала, что «организация производства продуктов питания» является областью быта, которая «до сих пор происходит за счет труда женщин» (Янкова 1970; Янкова 1972; Зуйкова 1977: 3, 7-8). Проблемы женского труда и быта затронула в своих трудах Л.Н. Кузнецова, ведь домашние дела по-прежнему выступали преимущественно женской заботой, являясь, однако, «важными и необходимыми для жизни семьи» (Кузнецова 1980: 3). Е.Б. Груздева и Э.С. Чертихина отмечали, что домашний труд - это «наиболее продолжительное занятие во внерабочее время», а недостаточное развитие торговли и в 1980-е годы продолжало «сдерживать процесс сокращения затрат труда» (Груздева, Чертихина 1983: 119, 122, 129).

С переосмыслением событий советского периода в 1990-2000-е гг. ученые пришли к выводу о том, что для советских женщин сохранялись традиционные домашние обязанности, а двойная нагрузка (на работе и дома) породила неравенство полов. Потому так важны были исследовательские задачи, намеченные Н.Л. Пушкаревой, которая первой предложила «делать знакомое незнакомым», изучать повторяющееся, привычное, «почти незамечаемое» для «воссоздания бытового антуража в контексте его создания» (Пушкарева 2005: 21, 33). Таким незаметным, но ежедневно необходимым и является в повседневности все, связанное с личным отношением женщин к процессу доставания и приготовления пищци, не случайно в последние десятилетия проблема гендерного разделения домашнего труда привлекла внимание 
массы социологов. В исследованиях Т.А. Мищенко, Н.В. Дулиной и Л.И. Вавулинской подчеркнуто, что с 1960-х гг. начался этап смешения гендерных ролей, продолжающийся и сегодня (Мищенко 2010; Дулина, Ануфриева 2015; Вавулинская 2016). Конкретные аспекты потребления продуктов питания стали интересовать ученых совсем недавно, а проблема распределения гендерных ролей и вовсе остается незатронутой (Томилин 2016; Таранова 2017; Еремина 2019).

Чтобы перейти к анализу собранного материала, полагаем важным напомнить о том, что женская литература в СССР начиналась с ныне полузабытой повести Натальи Баранской «Неделя как неделя». Ее главная героиня (сотрудница НИИ) после работы бежала домой с сумками продуктов, готовила ужин для всей семьи, чтобы в конце недели потеряться «в туче дел и забот» (Баранская 1969: 35, 46). В этой героине могли бы себя узнать все жительницы Нижнего Поволжья, о которых и пойдет речь. Основным источником пополнения семейных запасов была тогда в Сталинградской (с 1961 г. - Волгоградской) области государственная и кооперативная торговля. Правда, в годы войны большая часть предприятий общественного питания и торговли региона была уничтожена. Число новых предприятий стало быстро расти уже с конца 1940-х годов и к 1950 г. количество магазинов достигло довоенного уровня, к 1960 г. возросло в 1,3, а к 1965 г. - в 1,5 раза. К концу 1966 г. в городе с населением 1386,6 тыс. человек насчитывалось 819 магазинов (Народное хозяйство 1967: 25, 209-211). Рост оборота важнейших товаров народного потребления, к которым относили мясопродукты, рыбопродукты, масло животное, молоко, сахар, кондитерские изделия, наблюдался на протяжении всего периода, сбавив темпы к середине 1960-х гг. (Народное хозяйство 1967: 218).

Однако, несмотря на положительную статистику, в реальной жизни, обстановка с продуктами питания в регионе на протяжении 1950-1960-х гг., оставалась сложной. В условиях массового дефицита товаров, женщины были вынуждены прибегать к различным способам приобретения продуктов питания, многие из которых имели не совсем легальный характер. Так, в государственных магазинах горожанками приобреталось подавляющее большинство продуктов питания. Но, простаивая за ними в очередях, именно женщины легко завязывали новые знакомства, к тому же, представительницы женского пола составляли подавляющее большинство сотрудниц продуктовых (и не только) магазинов (ГАВО. Ф. Р-6036. Д. 36. Л. 46; Д. 90. Л. 32). Так, у одного рядового врача, жившей в Сталинграде (Волгограде) несколько послевоенных десятилетий, спустя несколько лет проживания в городе, уже были “свои сотрудники торговли”, которые могли “иногда предупредить”, так чтобы купить продукты с “помощью кассира” или “взять чеки без очереди”, что стало для покупательницы привычной обыденностью, о чем она и рассказала в своем дневнике (ГАВО. Ф. Р-6880. Д. 16. Л. 36, Л. 113об, Л. 118об).

Именно на женщин ложились заботы в приобретении продуктов питания, которые, зачастую, приходилось “добывать” нелегким путем. Походы по магазинам длились “допоздна”, ведь приходилось “обходить все магазины” в районе проживания, дабы “что-нибудь купить из продуктов”, но во многих из них “ничего нет, все очень трудно достать" - вынужденные обстоятельства становились для женщин чуть ли не ежедневным испытанием (ГАВО. Ф. Р-6880. Д. 25. Л. 123об, Л. 127; Д. 16. Л. 118об; Д. 21. Л. 55). Продукты то и дело, приходилось “доставать”, а сам процесс отнимал много времени и сил: «До 22 ч. мы с Дусей ходили по магазинам и с б/трудом достали продукты - топленое масло, вермишель, макароны... Вернулись поздно и 
уже уставшие»; «остаток вечера, после прогулки, допоздна по магазинам (искала масло сливочное и печенье московское)» (ГАВО. Ф. Р-6880. Д. 16. Л. 20; Д. 25. Л. 127). В своих воспоминаниях женщины также отмечают очереди не только за крайне необходимыми продуктами, но и заметно ускоряющими приготовление домашней пищи - полуфабрикатами (ПМА 1: Н.П.; Н.В.; А.И.; Р.А.).

От неожиданного изобилия продуктов покупательницы теряли голову. После посещения нового кондитерского магазина, зачастую приходилось осознавать, что “накупила всего, что с виду приглянулось, а приехав домой, ничего не показалось вкусным...”; покупать дорогие продукты, думая о том, “что стоят бумажки в виде 4 рублей по сравнению с настоящим визитом аппетита?” - становилось и духовной потребностью (ГАВО. Ф. Р-6880. Д. 19. Л. 168, Л. 169). Желание насладиться “вкусным”, превращало первостепенную необходимость в недосягаемые желания, список которых был достаточно широк и для женщины-врача, располагавшей не самым низким материальным достатком: “Поела бы ухи из мелкой рыбы - ершей, окуней, горохового супа, маринованных огурчиков или красных хорошего засола помидорчиков, поела бы трески с картофелем...” (ГАВО. Ф. Р-6880. Д. 19. Л. 169).

Женщины старались запасать впрок продукты, в особенности те, которые пропадали с прилавков. Нередко за товар отдавали последние деньги, настолько высок был страх того, что самое необходимое для приготовления каждодневной пищи, может исчезнуть в любой момент: “В магазинах дают муку. Дуся израсходовала последние деньги, купила 3 пакета муки на 51 р.”; “купила в манс. магазине № 8 1,600 гр. сливочного масла 1 кг перетопила, будет впрок” (ГАВО. Ф. Р-6880. Д. 13. Л. 145; Д. 31. Л. 72).

Острая нехватка продуктов, казалось, обходила стороной сотрудниц торговли, которые нередко злоупотребляли своими служебными обязанностями, принося желанные продукты домой. В городской комитет КПСС от граждан регулярно поступали жалобы о многочисленных проступках сотрудников продуктовых баз, общепита и торговли. Всеобщие нарушения приобретали поистине широкие масштабы - крупное уголовное дело было возбуждено в 1956 г. За многолетние нарушения торговли с нанесением ущерба в 129 тыс. руб. продовольственной базе № 6 ОРС/а, семья Дрынкиных была заключена под стражу и лишена всего имущества. В качестве сообщников к уголовному делу было привлечено 22 человека, 15 из них - женщины (ЦДНИВО. Ф. 71. Оп. 28. Д. 43. Л. 179-181).

Главный инженер Рагимова была задержана “с маслом и яйцами органами милиции в проходной хлебозавода", помимо этого, она “давала указания припрятать три мешка муки и несколько ящиков маргарина” (ЦДНИВО. Ф. 71. Оп. 21. Д. 64. Л. 62, Л. 66). За совершенные нарушения сотрудница завода была уволена. Неоднократно нарушала правила советской торговли и гражданка Злобина - заведующая магазином "Гастроном”. О том, как она “брала всевозможные продукты в отделах, не оплачивая ни за что денег” было сообщено и в региональную газету (ЦДНИВО. Ф. 71. Оп. 21. Д. 77. Л. 5). Коллективная жалоба сотрудников магазина и всеобщая огласка, позволили данные нарушения не только демонстративно огласить, но и прекратить. Однако боязнь потерять доверие и авторитет на рабочем месте, не останавливали нарушительниц. Продавщица магазина № 1 "Гастроном” Кутырева “допускала завышение цен при продаже пшена, сахара и делала обвес покупателей”, за что была привлечена к административной ответственности с объявлением строгого выговора (ЦДНИВО. Ф. 71. Оп. 21. Д. 77. Л. 13). А продавец Сазыкина завышала цены на “сыр галандский 1 сорта стоимостью 2 р. 50 коп., продавался по цене 2 р. 90 коп.”, в результате чего была уволена по собственному 
желанию (ЦДНИВО. Ф. 71. Оп. 37. Д. 66. Л. 49, Л. 50). Для того, чтобы накормить свою семью, поступаясь и моральными принципами, женщины нарушали закон, шли на рискованные поступки, однако не всегда несли за них наказание.

Выгодные знакомства играли огромную роль в снабжении продуктами питания, информанты часто говорят об этом: "Наша соседка работала на мясокомбинате, она нас снабжала, всегда было свежее мясо”; “Сестра работала в Обкоме, в отделе сельского хозяйства, туда привозили все, и она нам давала продукты: рыбу различную, кур, гусей, ананасы” (ПМА 1: Т.М.; Н.В.). В провинциальный город дефицитные продукты привозили из столичных регионов, о чем вспоминают жительницы города: “Моя двоюродная сестра в 1964 г. поступила в Ленинградский педагогический институт. Баловала нас тем, что привозила восточные сладости, рахат-лукум, ведь этого никогда не видели”; “Кофе нам сестра из Москвы привозила или в Обкоме доставала"; “Дефицит привозили из Москвы, отец ездил часто. Из дефицита апельсины, мандарины, привозили из Москвы”; "Моя мама ездила через Москву, и оттуда она привозила сосиски метрами, апельсины, сыры, колбасы” (ПМА 1: Г.Ю.; Н.В.; О.В.; Т.А.). Женщины считали своим долгом не просто накормить семью, но и побаловать деликатесами, которые, как правило, хранили для “сервировки праздничного стола” (ГАВО. Ф. Р-6880. Д. 21. Л. 26).

Колхозные рынки были призваны восполнить дефицит продукции государственных магазинов. Но даже на рынках наблюдались толпы очередей, находясь в которых, женщины были вынуждены тратить огромное количество времени: “Зашли на рынок ЗКО - все дорого и торгуются до одурения. Картофель у одной торговки, так у ней очередь человек 30 ! Купили огурцы и помидоры и поспешили домой...” (ГАВО. Ф. Р-6880. Д. 27. Л. 168об). Цены на продукты завышались, да и спрос покупательниц не всегда был удовлетворен, но на рынках горожанки покупали необходимые для питания мясо и овощи, нередко за продуктами посылали детей: "На рынок меня посылали. Десять рублей давали мне, и на эти десять рублей я покупала свинины, говядины, баранины по двести грамм на борщ”. А чтобы купить хороший кусок мяса, необходимо было встать засветло и занять очередь: “Мясо покупали на рынке. Вставали иногда в четыре часа, трамваи ещё не ходили, шли пешком до рынка. Люди жгли костры, грелись” (ПМА 1: А.И.; Л.Д.).

Именно женщины сталкивались с различными трудностями, считая каждую копейку, они были вынуждены отстаивать многочасовые очереди, а после - нести огромные сумки в руках домой (сумок на колесах тогда в советских магазинах не было). В первой половине 1950-х гг. за простыми яблоками могли стоять огромные очереди; дорвавшись до покупок, женщины (как они вспоминают) старались закупить не один килограмм: “Утром Дуся достала в магазине, простояв 2 часа в очереди - магазин открылся на 1,5 часа позже, 7 кг яблок по 3.60 и 5.60" (ГАВО. Ф. Р-6880. Д. 15. Л. 80). Несмотря на дороговизну, желанные фрукты и овощи приходилось покупать не без доли возмущения: “'Зашла на рынок, купила сочинскую черешню по 20 р. кг, вишни 15 р. кг и огурцы 2 р. кг. Как все дорого, малина 25 р. кг, абрикосы 25 р. кг, помидоры чуть ли не 40 р. кг!” (ГАВО. Ф. Р-6880. Д. 20. Л. 12). Нередки были перебои с мясом, а по завышенным ценам его покупка становилась и вовсе невозможной, в основном брали “обрежь" или “мясо на косточке”, но хозяйки умели приготовить из такого “сырья” не только повседневные, но и праздничные блюда (ГАВО. Ф. Р-6880. Д. 31. Л. 138; ПМА 1: О.В.; Г.П.; А.Д.).

Общественные столовые, являясь частью государственной торговли - были призваны обеспечить население уже готовой продукцией. Возрождение предприятий об- 
щественного питания проходило более медленными темпами (в отличие от предприятий розничной торговли), довоенный уровень был восстановлен лишь к концу 1950-х гг., а в 1965 г. вырос вдвое, но и население страны увеличивалось с каждым годом. К концу 1966 г. в регионе насчитывалось 407 столовых, каждое из предприятий должно было обслуживать свыше 1000 человек (Народное хозяйство 1967: 209, 211).

В обстановке дефицита продуктов, сотрудницы общественного питания пользовались своей властью, как могли. А они имели возможность приобрести желанные продукты без трудностей и очередей. При этом рядовые женщины предпочитали “доставать” в столовых не готовые блюда и даже не полуфабрикаты, а именно сами продукты, из которых готовили домашнюю еду, кто как умел и как кого научили старшие. Иное дело - что-то к празднику. Одна из наших информанток, работница столовой в 1960-е гг, рассказала: “Я могла и коробку конфет домой привезти, за деньги, не бесплатно, но их же негде было купить” (ПМА 1: Н.Е.). Если в семье имелся сотрудник общепита, даже дефицитные продукты становились рядовыми: “Свекровь работала зав-производством столовой, и на столе было все: и карбонат, и даже икра чёрная” (ПМА 1: А.И.). Желаемое приобреталось женщинами и в столовых учебных заведений: “Я через школу доставала мясо и сосиски, вместе с общим заказом и мне заказывали” (ПМА 1: Н.В.).

Стоит отметить, что многие предприятия общепита не соответствовали санитарным нормам. Так, рейдовая проверка 1963 г. заводских пунктов общественного питания обнаружила, что в столовой нефтебазы не было "раствора хлорной извести для мойки посуды”; в общепите № 18 “стены мойки покрыты грибком”; в столовой № 20 “в подсобках обнаружено присутствие грызунов” (ГАВО. Ф. Р-6821. Д. 14. Л. 31-33). Прийти на семейный обед в такую столовую никому бы в голову не пришло. В антисанитарном состоянии в 1961 г. была даже столовая педагогического института (№ 42), в которой обедали люди с высшим образованием, умеющие (казалось бы) отстоять свои права на достойное снабжение и чистоту своей “харчевни” (ЦДНИВО. Ф. 71. Оп. 37. Д. 27. Л. 111).

Трапеза вне дома не была для массы горожанок частой и распространенной формой досуга, к тому же в городе было в 1966 г. всего 4 ресторана и 4 кафе (Путеводитель по Волгограду 1966: 130-131). Любопытно, что обед или ужин в таком престижном пункте питания сопровождало нередко посещение театра или кино, это запоминалось как редкость, как событие в жизни, ведь даже свадьбы предпочитали праздновать в домашней обстановке (ПМА 1: Г.П.; А.И.; Н.Ф.). Кафе и рестораны респондентки вспоминают с удовольствием, повторяя полузабытые названия “Маяк”, “Волгоград”, “Дружба” - все они были в центре города (ПМА 1: Г.Ю.; Т.В.; Н.П.). Врач 3.С. Седельникова каждый раз записывала (и лишь с 1960 г.) посещение кафе и ресторанов; бывала там в компании мужчины, который и платил за еду. Однажды она записала, что в кафе “Дружба” на десерт был абрикосовый компот, о котором “давно мечтала”; это событие в жизни равноположено другому: в кафе-автомате она смогла “выпить сливки с булочкой” (ГАВО. Ф. Р-6880. Д. 25. Л. 68, Л. 181 об). Судя по ее записям, в ресторане "Сталинград” в самом центре вечно было “полно народу", зато на берегу Волги в "Маяке" - напротив, имелись свободные столики и всегда была возможность (обратим внимание на определение) “заказать сытный ужин” (ГАВО. Ф. Р-6880. Д. 26. Л. 43). Сытость - понятие благополучия для послевоенного поколения; возможность сытно поесть или накормить близкого приравнивалась к удачно проведенному свободному времени и, конечно, иногда освобождало женщину от каждодневных обязательств. 
Личные подсобные хозяйства горожанок на их дачах были тогда еще одним источником пополнения семейных запасов, как и колхозные рынки. В годы хрущевских реформ они, правда, сильно пострадали: горожанам запретили иметь в собственности скот, о чем женщины воспоминают с досадой: до того “мясо своё было в основном утки, но как Хрущёв ликвидировал, кроме кошки никаких животных” не осталось; "Не разрешали держать, а у нас были куры, свинья, все прятали в подвале" (ПМА 1: Р.А.; Н.А.). Устная история того времени позволяет увидеть эту иную картину женской повседневности, которая не попала ни в документы, ни в СМИ: “Молоко своё было, корова и десять кур на шести сотках”; “Держали курей, свиней, в сарае держали свиней” - в случае проверки приходилось платить штрафы (ПМА 1: Н.П.; М.П.).

С работой в выходные на земельном участке было проще. Выращивали овощи, неплохо росли ягоды и фрукты, из сельской местности их летом и осенью везли в город: «Огурцы и помидоры, яблоки, груши, нам бабушка из Ленинска привозила»; «У нас дача была, огород разбили, была и картошка, и малина, и яблони, груши» (ПМА 1: Г.Ю.; Л.Д.). Обладание дачным участком (у кого не было родных в деревне) было предметом зависти, именно с начала 1960-х гг. стала распространяться практика получения дачных “шести соток”. У владелиц дачных участков были «свои консервированные фрукты и овощи, особенно вкусный компот», а привезенная в подарок «тыква со своей дачи» сразу же отправлялась в духовку (ГАВО. Ф. Р-6880. Д. 28. Л. 107; Д. 25. Л. 122об). На дачные участки охотно ехали с друзьями, которые помогали собрать урожай, им с ними и делились (ГАВО. Ф. Р-6880. Д. 33. Л. 58). Дачные хозяйства немало помогали в снабжении продуктами питания, дополняли и обогащали повседневный и праздничный стол - всегда в то время домашний.

С трудом купленные, буквально добытые в очередях и по знакомству продукты волгоградка 1960-х гг., как правило, умела вкусно приготовить так, чтобы сытно накормить детей и других родственников. Умение готовить поддерживалось устной традицией (передавалось от старших женщин младшим), рецепты переписывались из журналов, отрывных календарей, книг, вроде «Книги о вкусной и здоровой пище» с разнообразными рецептами и соблазнительными фотографиями. С середины 1950х гг. внимание хозяек завоевало не менее популярное издание «Домоводство», вышедшее впервые в 1956 г. и с небольшими добавлениями переиздававшееся ежегодно (Домоводство 1956; Домоводство 1958; Домоводство 1960; Домоводство 1965). Книжки такого рода были в каждом доме, кулинарные рецепты из журналов и календарей нередко вклеивались в отдельные тетради или на страницы «Домоводства» напротив того продукта, о котором шла в книге речь. Иные из подобных изданий хранятся волгоградками, несмотря на возможности Интернета, по сей день (ПМА 1: Е.В.; Г.Ю.; О.В.; Т.М.; Л.М.; Л.Д.; Н.П.; Т.В.; Н.П.).

По-своему помогали в структурировании повседневного и праздничного стола и такие женские периодические издания - как «Работница», «Крестьянка» и «Советская женщина». Они не только отражали, но и в известном смысле формировали желаемую идеологами культуру потребления, в продвижении которой главную роль играли женщины. В кулинарных рубриках женских журналов, давались и кулинарные советы, и нехитрые способы облегчения домашнего труда (Советская женщина 1953. № 1: 60-61; Работница 1954. № 1: 27-28; Советская женщина 1955. № 2: 46; Работница 1959. № 10: 32) (рубрика «Кулинария» в журнале «Работница» была любима многими хозяйками, а раздел «Полезные советы» в журнале «Крестьянка» внимательно изучался каждой хозяйкой: там говорилось, как ухаживать за посудой 
и обеспечить семью заготовками на зиму (Работница 1954. № 4: 32; 1957. № 1: 31; Крестьянка 1953. № 11: 32; 1954. № 3: 32; 1956. № 9: 30-31). Любая хозяйка умела накрыть и праздничный стол; в Новый год он изобиловал мясными блюдами и сладостями (Крестьянка 1958. № 11: 30-31; 1962. № 1: 32). С середины 1960-х гг. страницы женских журналов стали площадкой обмена рецептами и советами (Крестьянка 1965. № 3: 32; № 5: 32; № 8: 32), в том числе о том, чем заменить мясо в условиях его дефицита и «как привести в годность забродившее варенье» (Крестьянка 1966. № 1: 32; 1966. № 3: 32). В еще более популярном, чем «Крестьянка» журнале «Работница» - женщин обучали, как сделать домашнее питание имеющим «приятный вид», быть питательным, недорогим и вкусным (Работница 1955. № 1: 32). Журнал учил, как - «придав красоту простым блюдам» - домашние хозяйки улучшат даже «самую скромную еду» (Работница 1960. № 12: 30). Продукты призывали использовать экономно, «чтобы домашний обед был вкусным и недорогим»; эта модель ведения хозяйства прочно внедрялась в женское сознание (Работница 1955. № 12: 32). Подобные призывы были более, чем актуальны, поскольку предпринимаемые государством попытки облегчить домашний труд женщин путем создания кухонь-столовых, удачей не увенчались (Работница 1955. № 11: 28-29; 1960. № 5: 30). Именно на страницах женских изданий можно почерпнуть информацию о новинках кухонной утвари, которые становились мечтой хозяек, чаще всего недоступной в нестоличном городе (Работница 1960. № 3: 31; 1960. № 10: 28; 1966. № 1: 29; 1966. № 8: 28).

В те годы даже холодильников в большинстве волгоградских семей не было; хозяйки обменивались знаниями о том, как сохранить скоропортящиеся продукты (Работница 1957. № 5: 31; 1959. № 5: 30; 1961. № 7: 31). Далеко не во всех семьях были умелые мужчины, могущие собрать холодильник по описанию, достать нужные детали и собрать самим, что обошлось бы «совсем недорого»; о холодильнике как о кухонной мечте в прессе стали писать лишь с середины 1960-х годов, как и давать советы о его «заботливом» использовании (Работница 1965. № 2: 31; 1966. № 7: 31). Отсутствие в семье холодильника отметили многие горожанки того времени: «Холодильника не было, папа вырывал глубокий колодец, была ледяная вода, в ведро опускали продукты»; «Брали всего грамм по двести, тогда холодильников не было, чтобы за два дня съесть»; «Холодильников не было, купили килограмм - должны были съесть» (ПМА 1: Н.П.; М.П.; А.Д.). Практика приобретать продукты “понемногу” заставляла женщин каждый день идти за покупками; у кого-то не было средств на покупку желанного, у кого-то - возможности. Вышеупомянутая врачиха отдала в 1958 г. за «Холодильник “Саратов-2” с автоматическим выключателем и включением, цена 1500 р.» последние деньги, да еще и занимать пришлось. Зато, писала она в дневнике, «следующим летом не придется страдать с продуктами от жары» (ГАВО. Ф. Р-6880. Д. 22. Л. 75). Электричество экономили, холодильник старались включать только в теплое время года, когда иным способом сохранить продукты было сложно: “Как мы рады, что имеем холодильник, тепло, а продукты уже не тревожат, не пропадут как раньше” (ГАВО. Ф. Р-6880. Д. 23. Л. 17). Важность покупки холодильника запечатлелась в памяти многих женщин; можно было наконец-то прекратить готовить каждый день, а некоторые продукты приобретать впрок (ПМА 1: Н.П.; А.Д.; И.В.). Отчасти в помощь хозяйкам оказывались традиционные способы хранения приготовленной еды (холодные подвалы в домах были, однако редкостью), но традиционная кухня народов СССР как раз легко находила дорогу к сердцам хозяек. С конца 1950-х гг. в кулинарных рубриках появились национальные рецепты, вносившие “некоторое разнообразие в питание” 
(Работница 1958. № 10: 31), в особенности те, которые позволяли использовать продукты не первой свежести (из одного только черствого хлеба предлагалось с десяток блюд) (Работница 1959. № 11: 32; 1965. № 3: 30). В отличие от “Крестьянки” и "Работницы”, журнал “Советская женщина” (адресованный активисткам-общественницам и, скорее, женщинам столицы, а не регионов) читался волгоградками редко; в нем если и попадались советы, то о сервировке праздничного стола и использовании возможностей заказа готовых блюд на дом (в СССР такая возможность появилась в 1953 г.). В Волгограде такое было в диковинку; если хозяйки и пользовались гастрономией в специальных отделах крупных магазинов, то, чтобы купить мясные полуфабрикаты или изредка что-то к праздничному столу (пирожные) (Советская женщина 1953. № 2: 58-59, 60-61, 63; 1956. № 3: 47; 1956. № 10: 47; 1957. № 1: 47; 1959. № 5: 46; 1960. № 1: 48). Крайне узкая часть волгоградских хозяек могла быть озадачена стремлением “быстро приготовить печенье к ужину”, организовать “обед на скорую руку” (Советская женщина 1954. № 10: 46; 1954. № 11: 44-45; 1960. № 2: 37), почти ни у кого не было ни миксеров, ни блендеров, хотя в «Советской женщине» писалось, что такие приборы “широко входили в наш быт” (Советская женщина 1955. № 2: 46; 1955. № 6: 47; 1956. № 8: 46-47; 1964. № 2: 38; 1965. № 7: 39). Специально не выписывался, но иногда просматривался горожанками начавший выходить в 1963 г. журнал “Служба быта”. В нем женщины тоже могли найти кулинарные советы, узнать об электробытовых новинках, поскольку приготовление пищи было признано "наиболее трудоемкой домашней работой” (Служба быта 1966. № 7: 34-35). Кухню журнал именовал “рабочим местом”, учил хозяек, как именно его организовать, при этом самой выглядеть “опрятно и красиво” (Служба быта 1964. № 3: 30-31; 1965. № 10: 30-32; 1966. № 12: 37).

Очевидно, что в непростых бытовых условиях первыми, кто мог бы помочь женщинам облегчить их домашний труд, в том числе в доставании продуктов, приготовлении еды, должны были бы быть мужья. Но традиции распределения семейных ролей менялись медленно; к делам приготовления еды, мытья посуды после нее, приучали, прежде всего, девочек: “Мы с сестрой маме помогали готовить вареники, блины, мясо в горшочке”; “готовила мама, лепили с ней пельмени, смотрели, как варить борщ”; “Я рано начала готовить, мне очень нравилось; в классе пятом я уже могла суп сварить, картошку пожарить, почистить овощи, все это подготавливала” (ПМА 1: Л.В.; Л.Д.; А.И.), мужья и отцы помогали в этих делах редко (ПМА 1: Т.А.; Г.Ю.; А.И.). Традиционно к домашней работе привлекали детей, дочери учились готовить у матерей и вместе с ними, реже (но все-таки случалось) привлекали и сыновей (ПМА 1: Т.А.). Дети накрывали на стол и убирали посуду, бегали в магазин за мелкими покупками (ПМА 1: Т.А.; Л.В.; Т.М.; С.В.).

Узкий слой городской элиты мог себе позволить найм домработницы, следить за нею и давать поручения принято было опять-таки женщинам. Так, семье бездетного врача 3.С. Седельниковой удалось уговорить прежде служившую в семье ее бывшего мужа помощницу, перебраться к ней: “Жду Дусю к себе, с ней лучше, обед будет вовремя и вкусный” (ГАВО. Ф. Р-6880. Д. 13. Л. 65). Домработница зачастую спала с хозяйкой в одной комнате, превращаясь постепенно из прислуги в подругу, наперсницу, подопечную, о которой приходилось заботиться: кормить и одевать. Домработница закупала продукты, готовила домашнюю пищу, в ее обязанности входила и уборка. В таких редких семьях, где были домашние помощницы, заботы по доставанию, покупке и приготовлению продуктов делились женщинами между друг другом и сокращали число «нескончаемых работ». Редко, кому везло с мужем настолько, что он готов был взять на себя часть работ 
по приготовлению пищи. Однако если на какие-то “женские работы” мужчина и соглашался, это чаще всего была уборка с помощью пылесоса , а чаще всего - именно приготовление пищи при наличии нужных продуктов дома. Врач 3.С. Седельникова записала как-то в дневнике: “Домой пришла в начале третьего, ВИ обтирал полы в балконе, в комнате чисто, в кухне обед - борщ и бефстроганов” (ГАВО. Ф. Р-6880. Д. 30. Л. 151). Бездетная интеллигентная пара старалась сделать домашние дела, как можно скорее, чтобы выкроить свободное время на досуг (“Купили в главгастрономе и полуфабрикатах продукты, поспешили домой. ВИ готовил борщ, а я блинчики с мясом, чтобы завтра вечер был свободным") (ГАВО. Ф. Р-6880. Д. 31. Л. 11).

Такая благостная семейная обстановка была далеко не у всех. У большинства женщин в городе не было широкого круга знакомств для доставания продуктов, перебои же со снабжением были перманентными: “Масла сливочного и топленого, сахару, круп нет уже несколько месяцев”, - признавалась автор дневника начала 1950х гг; “Вернулась домой, пробежав по магазинам; с продуктами плохо - ни сахара, ни круп (кроме манной), ни мясных изделий, ни овощей!” (ГАВО. Ф. Р-6880. Д. 15. Л. 239об; Д. 16. Л. 15, Л. 15об). Ситуация не изменилась и в первой половине 1960-х гг. (“Искала в гастрономах творог и не нашла, сыра хорошего опять нет”; "В магазине очередь - ждут сахар, недели две как исчез в магазинах, вероятно будут давать по спискам!”; и даже “Ходила за хлебом, вернулась с пустыми руками, нет хлеба!”) (ГАВО. Ф. Р-6880. Д. 28. Л. 67; Д. 30. Л. 25, Л. 127об).

В день выплаты зарплаты бежали за продуктами, чтобы приобрести вкусности, на которые в другие дни тратиться не решались (ГАВО. Ф. Р-6880. Д. 16. Л. 80об; Д. 17. Л. 25; Д. 18. Л. 187; ПМА 1: С.В.; Т.А.; А.Д.). Об отсутствии простых и нужных продуктов даже сегодня респондентки говорили с негодованием: “Был момент, первая половина 1960-х, перебои с хлебом, кроме пятнадцатикопеечного кукурузного хлеба ничего не было”; “Не было апельсинов, мандаринов, даже в новогодних подарках не было, не было зимой и яблок”; “риса не было, манки, ели в основном пшено” (ПМА 1: Т.А.; Г.Ю.; Н.П.). Женщины переживали о том, что семья не накормлена. Желанные дорогие продукты, приобретенные “на праздник”, вспоминаются с чувством горечи (ГАВО. Ф. Р-6880. Д. 13. Л. 119об, Л. 120): вся жизнь в то время была выживанием, борьбой за продукты, и редко, у кого были знакомства с продавщицами и сотрудницами общепита. Практически все, говоря о том времени, вспоминают, что еда тогда была “простая". "Майонеза мы не знали, мы про него не слышали”; “ели картошку в мундире с селедкой, грибы, просто и в тоже время сытно”; "Простая была еда: картошка, помидоры, огурцы, капуста”; “мама не готовила особых блюд”, как обыденная еда названы, однако, и плов, и жареный цыпленок (ПМА 1: О.В.; Т.А.; И.В.; Н.П.). Вспоминая мамины умения, респондентки говорят, что “вроде и не было ничего", но матери умели “делать подливы разные, они обогащали питание”; “пекли пироги с капустой, рыбой, мясом, сладкие с сухофруктами, плюшки с сахаром" (ПМА 1: Н.А.; Г.Ю.; Т.А.). Как память о детстве остались в рассказах “мамины пирожки”, “суп с фрикадельками, плов”; лапшевник (“лапша, сверху яйца и в духовку”) (ПМА 1: О.В.; Р.А.; Н.П.).

Домашние разносолы традиционно были частью русского обыденного и праздничного стола; бытовало слово “закрутки”, наличие в продаже крышек и умение пастеризовать заготовки обеспечивало устойчивую практику делать летом заготовки на всю зиму, особенно если семья летом жила на даче. "Компоты, закрутки делали, квашеную капусту, сало солили, сами делали - так намного дешевле было”; “Грибы солили, по- 
мидоры, огурцы, капусту”; “Мама закрывала всякие компоты, овощи, салаты” (ПМА 1: Н.А., О.В.; Т.А.; Л.Д.). Заготавливали сразу помногу (“15 кг огурцов в 12 банках”; “закрутили 15 кг огурцов”), на работе в такие летние дни женщины брали отгулы исключительно, чтобы заняться закрутками на зиму (ГАВО. Ф. Р-6880. Д. 30. Л. 181; Д. 33. Л. 226) и тратили огромную часть своего свободного времени: “солили капусту, чем после обеда и занимались до 9 часов, засолили 32 кг в 2-х бочках"; “18 кг чудесных помидор нынче замариновали в 21 банку; устали, но довольны” (ГАВО. Ф. Р-6880. Д. 32. Л. 55; Д. 35. Л. 35). Ловля рыбы изредка выступала женской практикой и видом отдыха, а вот поход за грибами, дальнейшая их разделка и консервирование, являлись не только формой досуга, но и существенным подспорьем в домашнем питании (ПМА 1: Т.А.; Л.Д.). Правда, на данное занятие уходили не только силы и время, после приходилось “считать царапины на ногах" и отмывать руки, которые “остались темными и после душа”, однако все заботы восполнял “особый вкус ужина с грибами собственного сбора” (ГАВО. Ф. Р-6880. Д. 25. Л. 86об).

Нередкими были сетования женщин на домашний труд, у врача 3.С. Седельниковой на готовку (при наличии домработницы!) все равно уходила большая часть свободного времени: “С утра и до 10 часов возилась в кухне, готовила обед (какую уйму времени ежедневно отнимает эта кухонная и хозяйственная работа!)” (ГАВО. Ф. Р-6880. Д. 33. Л. 222). На “стряпню”, как это она называла, мог уйти и целый вечер, и предназначенный для отдыха выходной (ГАВО. Ф. Р-6880. Д. 14. Л. 113об, Л. 186об; Д. 27. Л. 66об; Д. 28. Л. 58; Д. 30. Л. 76; Д. 32. Л. 102; Д. 33. Л. 213). Что и говорить о простых горожанках, не мечтавших о домашних помощницах (ПМА 1: И.В.; Т.А.; О.В.).

И уж в праздники наполнение и оформление стола всегда было обязанностью именно хозяйки. "Накрыть стол - это сто раз пройти до кухни и обратно. Приготовила на 20 персон” - писала врач, сожалея, что не успевала толком попраздновать. “Почти не могла следить за столом, все возилась в кухне и бегала от стола на кухню и назад. Удовольствия от вечера для себя никакого не получила, трудилась в поте лица. Зато рада, что гости были довольны” (ГАВО. Ф. Р-6880. Д. 18. Л. 214; Д. 22. Л. 37). Надолго оставалось и чувство горечи, если гости были нежданными и их вдруг не удавалось накормить: "Никогда так не переживала за невозможность угостить, ничего, кроме чая с сахаром и хлебом”; “чувствовала неловкость, желание угостить более вкусным обедом” (ГАВО. Ф. Р-6880. Д. 14. Л. 156; Д. 25. Л. 64). За неимением нужных продуктов, приходилось изменять рецептуру излюбленных блюд, а продукты на праздник в беспокойстве приобретать в избытке, “чтоб точно хватило” (ГАВО. Ф. Р-6880. Д. 15. Л. 122, Л. 291). В провинциальном городе женщины воистину становились “символами тягот, статуями нехваток и очередей”, как писал о женщинах в те годы популярный советский поэт Борис Слуцкий (Слуиякий 1966).

Бесспорно, именно в годы знаменитой хрущевской “оттепели” изменилась не только общественно-политическая ситуация, но и отношение к частной жизни людей. Именно тогда на государственном уровне впервые задумались над содержанием экономически до того невидимого женского домашнего труда, над возможностью его облегчить. Именно в то десятилетие по всей стране появились предприятия общественного питания, именно тогда в развитии направлений промышленности произошли перемены, и стало больше производиться предметов потребления, в том числе бытовых электроприборов, да и просто кухонной утвари. Однако до провинциальных городов нововведения докатывались с большим опозданием. Предпринятые государством усилия были практически не известны, не оказали еще существенного влияния на жен- 
ский повседневный быт. В условиях скрытого дефицита продовольственных товаров горожанки вынуждены были прибегать к разным способам “доставания” продуктов и приготовления пищи из минимума того, что требовалось для питания семьи. Домашний труд, в котором чистка, нарезка, готовка, организация диеты и обычного питания, уборка после еды, заготовка впрок составляли значительную часть, продолжал отнимать у женщин много свободного времени, а зачастую сна и отдыха. Он был не делом свободного выбора, но прямой необходимостью, которую женщины (успокаивая себя и примиряя с действительностью) старались сделать частью домашнего досуга. В отличие от мужчин, именно женщины отводили домашнему труду очень много времени, к тому их готовило и домашнее, и общественное воспитание, намекая на извечность этой социальной обязанности и гендерной роли. Домашнее, а не общественное питание, было основной формой потребления в провинциальном городе Нижнего Поволжья. Жительницы этого города, совмещая множество социальных ролей, неся двойную нагрузку (на работе и дома), ежедневно выполняли свои обязательства, нанося ущерб профессиональным перспективам, здоровью, отдыху и, не осознавая этой дискриминации, продолжали выполнять вмененные им обществом традиционно «женские» домашние обязанности, считали такое проведение свободного времени формой досуга.

\section{Источники и материалы}

Баранская 1969 - Баранская Н. Неделя как неделя // Новый мир, 1969. № 11. С. 23-55. ГАВО Ф. Р-6880 - Государственный архив Волгоградской области (ГАВО). Коллекция документов медицинских работников. Ф. Р-6880. Оп. 6.

ГАВО Ф. Р-6036 - Государственный архив Волгоградской области (ГАВО). Волгоградский универмаг. Ф. Р-6036. Оп. 3.

ГАВО Ф. Р-6821 - Государственный архив Волгоградской области (ГАВО). Красноармейский районный комитет народного контроля гор. Волгограда. Ф. Р-6821. Оп. 1.

Домоводство 1956 - Домоводство / сост. А.А. Демезер, М.Л. Дзюба. М.: Сельхозгиз, 1956. Домоводство 1958 - Домоводство / сост. А.А. Демезер, М.Л. Дзюба. М.: Сельхозгиз, 1958. Домоводство 1960 - Домоводство. М.: Сельхозгиз, 1960. 792 с.

Домоводство 1965 - Домоводство. М.: Колос, 1965. 759 с.

Книга о вкусной 1952 - Книга о вкусной и здоровой пище. М.: Пищепромиздат, 1952. 400 с. Книга о вкусной 1954 - Книга о вкусной и здоровой пище. М.: Пищепромиздат, 1954. 400 с. Книга о вкусной 1961 - Книга о вкусной и здоровой пище. М.: Пищепромиздат, 1961. 424 с. Крестьянка 1953 - Крестьянка 1953. № 11.

Крестьянка 1954 - Крестьянка 1954. № 3.

Крестьянка 1956 - Крестьянка 1956. № 9.

Крестьянка 1958 - Крестьянка 1958. № 11.

Крестьянка 1962 - Крестьянка 1962. № 1.

Крестьянка 1965 - Крестьянка 1965. № 3, № 5, № 8.

Крестьянка 1966 - Крестьянка 1966. № 1, № 3.

Народное хозяйство 1967 - Народное хозяйство Волгоградской области за 50 лет. Волгоград: Ниж.-Волж. кн. изд-во, 1967. 263 с.

ПМА 1 - Полевые материалы автора г. Волгоград. Апрель 2019 г. - март 2020 г. (информанты - Мери Петровна, 1933 г.р.; Нина Федоровна, 1933 г.р.; Раиса Александровна, 1935 г.р.; Ираида Васильевна, 1937 г.р.; Нина Васильевна, 1938 г.р.; Нина Петровна, 1941 г.р.; Нелли Андреевна, 1942 г.р.; Анна Дмитриевна, 1943 г.р.; Елена Васильевна, 1944 г.р.; Галина Петровна, 1945 г.р.; Нина Евгеньевна, 1945 г.р.; Татьяна Викторовна, 1948 г.р.; Антонина Ивановна, 1948 г.р.; Людмила Дмитриевна, 1948 г.р.; Татьяна Михайловна, 1950 г.р.; Галина Юрьевна, 1951 г.р.; Ольга Владимировна, 1953 г.р.; Татьяна Александровна, 1954 г.р.; Нина Петровна, 1956 г.р.; Любовь Валентиновна, 1956 г.р.; Любовь Михайловна, 1958 г.р.; Светлана Владимировна, 1960 г.р.). 
Путеводитель по Волгограду 1966 - Монахова Н.Д. Путеводитель по Волгограду. Волгоград: Ниж.-Волж. кн. изд-во, 1966. 136 с.

Работница 1954 - Работница 1954. № 1, № 4.

Работница 1955 - Работница 1955. № 1, № 11, № 12.

Работница 1957 - Работница 1957. № 1, № 5.

Работница 1958 - Работница 1958. № 10.

Работница 1959 - Работница 1959. № 5, № 10, № 11.

Работница 1960 - Работница 1960. № 3, № 5, № 10.

Работница 1961 - Работница 1961. № 7.

Работница 1965 - Работница 1965. № 2, № 3.

Работница 1966 - Работница 1966. № 1, № 7, № 8.

Служба быта 1964 - Служба быта 1964. № 3.

Служба быта 1965 - Служба быта 1965. № 10.

Служба быта 1966 - Служба быта 1966. № 7, № 12.

Слуцкий 1966 - Слуцкий Б. Ключ (1966 г.). Доступ: https://45parallel.net/boris_slutskiy/klyuch. html (дата обращения: 16.06.2020).

Советская женщина 1953 - Советская женщина 1953. № 1, № 2.

Советская женщина 1954 - Советская женщина 1954. № 10, № 11.

Советская женщина 1955 - Советская женщина 1955. № 2, № 6.

Советская женщина 1956 - Советская женщина 1956. № 3, № 8, № 10.

Советская женщина 1957 - Советская женщина 1957. № 1.

Советская женщина 1959 - Советская женщина 1959. № 5.

Советская женщина 1960 - Советская женщина 1960. № 1, № 2.

Советская женщина 1964 - Советская женщина 1964. № 2.

Советская женщина 1965 - Советская женщина 1965. № 7.

ЦДНИВО Ф. 71 - Центр документации новейшей истории Волгоградской области (ЦДНИВО). Волгоградский городской комитет КП РСФСР. Ф. 71. Оп. 21, 28, 37.

\section{Научная литература}

Араловеи Н. Женский труд в промышленности СССР. М.: Профиздат, 1954. 176 с.

Белова В.С. Подлинное равноправие (Консультация при разработке лекций о роли советской женщины в строительстве коммунизма). М.: Знание, 1965. 40 с.

Бильшай В. Решение женского вопроса в СССР. М.: Гос. изд-во полит. и науч. лит., 1959. 264 с.

Вавулинская Л.И. Проблема женской занятости в 1950-х гг. (на материалах Карелии) // Женщина в российском обществе, 2016. № 2 (79). С. 82-90.

Гордон Л.А., Клопов Э.В. Человек после работы. Социальные проблемы быта и внерабочего времени. М.: Наука, 1972. 268 с.

Груздева Е.Б., Чертихина Э.С. Труд и быт советских женщин. М.: Политиздат, 1983. 222 с.

Грушин Б.А. Свободное время: Актуальные проблемы. М.: Мысль, 1967. 175 с.

Дулина Н.В., Ануфриева Е.В. Домашний труд в системе распределения гендерных ролей (по итогам прикладного социологического исследования). Известия Волгоградского государственного технического университета. Серия: Проблемы социально-гуманитарного знания, 2015. Т. 23. № 9 (72). С. 45-51.

Еремина О.Ю. Снабжение и потребление продуктов питания в СССР // Роль и значение советских пятилеток в развитии страны (к 90-летию первого пятилетнего плана). Материалы Всероссийской научно-практической конференции «Роль и значение советских пятилеток в развитии страны (к 90-летию первого пятилетнего плана)» / отв. ред. В.И. Коренев. Курск: Университетская книга, 2019. С. 37-41.

Зуйкова Е.М. Быт при социализме. М.: Изд-во Моск. ун-та, 1977. 240 с.

Кузнецова Л.Н. Женщина на работе и дома. М.: Политиздат, 1980. 231 с.

Куприн О. Быт - не частное дело. М.: Госполитиздат, 1959. 70 с.

Мищенко Т.A. Динамика социальных ролей трудящейся женщины в СССР как фактор трансформации семейного лидерства (1960-е - начало 1980-х гг.). Известия Уральского государственного 
университета. Серия 1: Проблемы образования, науки и культуры, 2010. Т. 85. № 6-2. С. 269-278.

Пушикарева Н.Л. «История повседневности» и этнографическое исследование быта: расхождения и пересечения // ГЛАСНИК ЕТНОГРАФСКОГ ИНСТИТУТА САНУ, 2005. № 53. С. 21-34.

Таранова О.A. «Здоровая пища» в СССР. Трансформация советских практик здорового и правильного питания // Глобальные социальные трансформации XX - начала XXI вв. (к 100-летию русской революции). Материалы научной конференции ХІ Ковалевские чтения» / отв. ред. Ю.В. Асочаков. СПб.: Скифия-Принт, 2017. С. 1556-1557.

Томилин В.Н. Структура питания основных категорий городского и сельского населения СССР в период политического лидерства Н.С. Хрущева // Гуманитарные исследования центральной России, 2016. № 1 (1). С. 43-53.

Харчев А.Г., Голод С.И. Профессиональная работа женщин и семья. Л.: Наука. Ленингр. отд-ние, 1971.

Янкова 3.А. О бытовых ролях работающей женщины (к проблеме осуществления фактического равенства женщины с мужчиной) // Проблемы быта, брака и семьи. Вильнюс: Минтис, 1970. С. 42-49.

Янкова 3.А. Изменение структуры социальных ролей женщин в развитом социалистическом обществе и модель семьи. Доклад ХІІ МСИС ССА, ИКСИ АН СССР. М.: б.и., 1972. 12 с.

\section{Pushkareva, Natalia and Irina Bogdashina}

\section{"Tasty and Healthy Food" in Everyday Women's Practices of a Non-Capital Soviet City in the 1950-1960s}

DOI: $10.33876 / 2311-0546 / 2021-53-1 / 260-274$

Everyday life of Soviet women in the 1950s-1960s is rarely a subject of ethnographic observation. This article focuses on such an important aspect of this life as purchase and preparation of food and issues related to cooking, providing food for children, relatives and friends in the Volgograd region while the economy was recovering after the World War II. Using ego-documents of a large non-capital region of the Lower Volga the study identified and compared the common and the particular in everyday cooking practices, clarified the attitude of women themselves towards the efforts undertaken by the state to facilitate their domestic work as housewives, identified semi-legal (bypassing the queue, purchasing "under the counter") and illegal (nepotism) ways of "feeding" their families. In conditions of a hidden shortage of goods, women faced many difficulties (queues, shortages, deprivations), but continued to bear the burden of endless household chores, sometimes considering the time spent on them as a form of rest and leisure.

Key words: gender anthropology, female domestic work, cooking, consumption, "Khrushchev thaw", Volgograd

For Citation: Pushkareva, N.L. and I.V. Bogdashina. 2021. "Tasty and Healthy Food" in Everyday Women's Practices of a Non-Capital Soviet City in the 1950-1960s. Herald of Anthropology (Vestnik Antropologii) 1 (53): 260-274.

*Pushkareva Natalya L. - Dr. in History, Head of the Centre for gender studies, Institute of Ethnology and Anthropology RAS (Moscow, Russia). E-mail: pushkarev@mail.ru

Bogdashina, Irina V. - Postgraduate Student, Institute of Ethnology and Anthropology RAS (Moscow, Leninsky Pr. 32A). E-mail: ira18bogdashina@mail.ru

The research was supported by the Russian Foundation for Basic Research (RFFI, project No. 19-09-00191) and is published as a part of the Research Plan of the Institute of Ethnology and Anthropology RAS

\section{References}

Aralovec, N. 1954. Zhenskij trud v promyshlennosti SSSR [Female labor in the industry of the USSR]. Moscow: Profizdat.

Belova, V.S. 1965. Podlinnoe ravnopravie (Konsul'taciya pri razrabotke lekcij o roli sovetskoj 
zhenshchiny $v$ stroitel'stve kommunizma) [True Equality (Consultation in the development of lectures on the role of Soviet women in the construction of communism)]. Moscow: Znanie.

Bil'shaj, V. 1959. Reshenie zhenskogo voprosa $v$ SSSR [Solution of the female issue in the USSR]. Moscow: Gosudarstvennoe izdatel'stvo politicheskoj i nauchnoj literatury.

Dulina, N.V., and E.V. Anufrieva. 2015. Domashnij trud v sisteme raspredeleniya gendernyh rolej (po itogam prikladnogo sociologicheskogo issledovaniya) [Domestic work in the system of distribution of gender roles (based on the results of applied sociological research)]. Izvestiya Volgogradskogo gosudarstvennogo tekhnicheskogo universiteta. Seriya: Problemy social'nogumanitarnogo znaniya Vol. 23.9 (72): 45-51.

Eremina, O.Yu. 2019. Snabzhenie i potreblenie produktov pitaniya v SSSR [Supply and consumption of food in the USSR] In: Rol' $i$ znachenie sovetskih pyatiletok $v$ razvitii strany (k 90-letiyu pervogo pyatiletnego plana). Materialy Vserossijskoj nauchno-prakticheskoj konferencii «Rol' i znachenie sovetskih pyatiletok v razvitii strany (k 90-letiyu pervogo pyatiletnego plana)», edited by V.I. Korenev. Kursk: Universitetskaya kniga.

Gordon, L.A., and E.V. Klopov. 1972. Chelovek posle raboty. Social'nye problemy byta i vnerabochego vremeni [Man after work. Social problems of life and after-hours]. Moscow: Nauka.

Gruzdeva, E.B., and E.S. Chertihina. 1983. Trud i byt sovetskih zhenshchin [Labor and life of Soviet women]. Moscow: Politizdat.

Grushin, B.A. 1967. Svobodnoe vremya: Aktual'nye problemy [Free time: Actual problems]. Moscow: Mysl'.

Harchev, A.G., and S.I. Golod. 1971. Professional'naya rabota zhenshchin i sem'ya [Professional work of women and family]. Leningrad: Nauka. Leningradskoe otdelenie.

Kuznecova, L.N. 1980. Zhenshchina na rabote $i$ doma [Woman at work and at home]. Moscow: Politizdat.

Kuprin, O. 1959. Byt - ne chastnoe delo [Life - is not a private matter]. Moscow: Gospolitizdat.

Mishchenko, T.A. 2010. Dinamika social'nyh rolej trudyashchejsya zhenshchiny v SSSR kak faktor transformacii semejnogo liderstva (1960-e - nachalo 1980-h gg.) [The dynamics of the social roles of a working woman in the USSR as a factor in the transformation of family leadership (1960s - early 1980s)]. Izvestiya Ural'skogo gosudarstvennogo universiteta. Seriya 1: Problemy obrazovaniya, nauki i kul'tury. Vol. 85. 6-2: 269-278.

Pushkareva, N.L. 2005. "Istoriya povsednevnosti" i etnograficheskoe issledovanie byta: raskhozhdeniya i peresecheniya ["History of everyday life" and ethnographic study of everyday life: discrepancies and intersections]. Glasnik etnografskog instituta sanu 53: 21-34.

Taranova, O.A. 2017. "Zdorovaya pishcha" v SSSR. Transformaciya sovetskih praktik zdorovogo i pravil'nogo pitaniya ["Healthy food" in the USSR. Transformation of the Soviet practices of healthy and proper nutrition] In: Global'nye social'nye transformacii XX-nachala XXI vv. (k 100-letiyu russkoj revolyucii). Materialy nauchnoj konferencii XI Kovalevskie chteniya», edited by Yu.V. Asochakov. St. Petersburg: Skifiya-Print.

Tomilin, V.N. 2016. Struktura pitaniya osnovnyh kategorij gorodskogo i sel'skogo naseleniya SSSR v period politicheskogo liderstva N.S. Hrushcheva [The nutrition structure of the main categories of urban and rural population of the USSR during the period of political leadership Khrushchev]. Gumanitarnye issledovaniya central'noj Rossii 1 (1): 43-53.

Vavulinskaya, L.I. 2016. Problema zhenskoj zanyatost v 1950-h gg. (na materialah Karelii) [The problem of female employment in the 1950s (based on materials from Karelia)]. Zhenshchina $v$ rossijskom obshchestve 2 (79): 82-90.

Yankova, Z.A. 1970. O bytovyh rolyah rabotayushchej zhenshchiny (k probleme osushchestvleniya fakticheskogo ravenstva zhenshchiny s muzhchinoj) [On the domestic roles of a working woman (on the problem of realizing the equality of women with men)]. In: Problemy byta, braka i sem'i. Vil'nyus: Mintis.

Yankova, Z.A. 1972. Izmenenie struktury social'nyh rolej zhenshchin v razvitom socialisticheskom obshchestve i model'sem 'i. Doklad XII MSIS SSA, IKSI AN SSSR [Changing the structure of women's social roles in a developed socialist society and the family model. Report XII ICIS SSA, ICSI of the USSR Academy of Sciences]. Moscow: b.i.

Zujkova, E.M. 1977. Byt pri socializme [Life under socialism]. Moscow: Izdatel'stvo Moskovskogo universiteta. 